\title{
Appearance of aldehydes in the surface layer of lake waters
}

\author{
Agata Dąbrowska • Jacek Nawrocki • \\ Elżbieta Szeląg-Wasielewska
}

Received: 25 September 2013 / Accepted: 6 March 2014 / Published online: 28 March 2014

(C) The Author(s) 2014. This article is published with open access at Springerlink.com

\begin{abstract}
The paper presents results concerning the changes in the content of aldehydes in samples of lake water collected near the lake surface. The study of lake waters was undertaken to explain which physicochemical parameters of the environment have the greatest influence on the level of aldehydes, which of the aldehydes are most often met in surface water and in what concentrations. We observed that formaldehyde, acetaldehyde, propanal, glyoxal, methylglyoxal and acetone were commonly present in surface water samples, while semi-volatile and poorly soluble aldehydes such as nonanal and decanal were observed seasonally. The contents of total aldehydes varied in a wide range, from 55 to $670 \mu \mathrm{g} / \mathrm{l}$, and the concentration of total organic carbon varied significantly from 3 to $18 \mathrm{mg} / 1$, but there was no evident correlation between them in all of samples. The total content of aldehydes did not depend on the meteorological parameters such as air temperature, UV radiation and ozone concentration; however, it was noted that the level of carbonyl concentration is related to the period of intense precipitation: in the period of very low precipitations, the highest contents of total aldehydes were determined in all of the water samples,
\end{abstract}

\footnotetext{
A. Dąbrowska $(\varangle) \cdot$ J. Nawrocki

Department of Water Treatment Technology, Faculty of Chemistry, A. Mickiewicz University, ul. Umultowska 89B, 61-614 Poznań, Poland e-mail: agatadab@amu.edu.pl

E. Szelag-Wasielewska

Department of Water Protection, Faculty of Biology, A.

Mickiewicz University,

ul. Umultowska 89, 61-614 Poznań, Poland
}

and in the periods of intense precipitations, the content of total aldehydes was drastically smaller.

Keywords Aldehydes · Total organic carbon · Surface water - Lakes · Precipitation

\section{Introduction}

Aldehydes are commonly found in the environment. Their presence can be controversial as they belong to the group of compounds potentially charged with considerable toxicity and carcinogenic and mutagenic properties (Richardson et al. 2007; Hebert et al. 2010; Rice et al. 2012). Aldehydes can cause an undesirable odour in natural surface waters (Nijssen et al. 1996; Bao et al. 1997). They can originate from a number of sources related to the oxidation processes, photochemical transformations, life processes of animals and plants and decomposition of organic matter. A significant part of aldehydes are formed in the atmosphere and their main precursors are organic compounds of natural or anthropogenic origin. The reaction of the commonly present oxidants (such as ozone, hydrogen peroxide or hydroxyl radicals) with the hydrocarbons has an important influence on the formation of carbonyl compounds in the troposphere (Warneck 2005; Possanzini et al. 2007; Myriokefalitakis et al. 2008; Obermeyer et al. 2009).

Another natural source of aldehydes is their emission from the plants, related to the vegetation processes (Wildt et al. 2003; Geron et al. 2006; Hu et al. 2008, 
2011). As suggested by $\mathrm{Hu}$ et al. (2008, 2011), aldehydes can be released from plants in response to the environmental stress imposed by pests eating plant leaves, diseases caused by fungi parasites or to repel the competitors. $\mathrm{Hu}$ and co-workers have identified more than ten aldehydes emitted by plants, including the saturated aldehydes such as acetaldehyde and C4$\mathrm{C} 13$, the unsaturated ones - hexanal and nonenal, benzaldehyde and furfural. The aldehydes accumulating in the atmosphere are periodically removed from it by dry deposition with falling dust or by wet deposition - with precipitations (rain, snow, hail or fog) (Kawamura et al. 2000, 2001; Matsunaga and Kawamura 2000; Matsunaga et al. 2007). The precipitations have been checked for the presence of organic and inorganic pollutants. Formaldehyde, acetaldehyde, glyoxal, methylglyoxal and acetone are the carbonyls most often determined in rain and described in literature (Matsunaga and Kawamura 2000; Kawamura et al. 2001; Matsumoto et al. 2005; Matsunaga et al. 2007; Li et al. 2008; Basheer et al. 2010). These aldehydes can also be present in surface waters. They can be formed in the processes of oxidation, photochemical transformations, living processes of microorganisms and water vegetation, so in similar processes as in the atmosphere. Jalliffier-Merlon et al. (1991) pointed to the participation of phytoplankton in the production of aldehydes $\mathrm{C}_{6}$ to $\mathrm{C}_{13}$ at the mouth of the Rhône River. They noted a strong correlation between the phytoplankton biomass expressed as the content of $a$ chlorophyll and the total concentration of aldehydes. The same authors reported a decrease in the aldehyde concentration with increasing water temperature, which they explained to be caused by the high volatility of aldehydes and an increase in intensity of biodegradation processes in summer. They suggested the use of aldehydes as biomarkers of biological life in surface waters, e.g. an increased concentration of nonanal can indicate the presence of hardly detectable blue algae (Cyanophyceae). Hammes et al. (2007) observed an effect of the phytoplankton on a significant increase in the content of aldehydes, ketones and carboxylic acids in the water collected from Lake Zurich and treated by ozone.

The presence of aldehydes in surface waters has been rather poorly recognised in literature. It has not been established whether the content of aldehydes in surface waters is related only to the conditions of biological life and transformation of organic matter in the water or it also depends on the external factors and deposition of carbonyl compounds from the atmosphere. The systematic study of the near-surface layer of lake water was undertaken to explain if the content of aldehydes depends on the atmospheric conditions, which of the aldehydes are most often met in surface water and in what concentrations and which physicochemical parameters of the environment have the greatest influence on the level of aldehydes.

This paper presents results of the aldehyde determination in water samples collected from the surface layer of a few lakes and their relation with the amount of precipitations, season of the year, concentration of ozone, intensity of UV radiation and content of total organic carbon and particulate matter suspended in the waters (defined as seston). The analysis of aldehydes was performed by the method proposed by the US Environmental Protection Agency (Method 556.1, Revision 1.0, September 1999) with a preliminary derivatisation process and separation of the created oxymes by gas chromatography in the configuration with electron capture detector.

\section{Materials and methods}

\section{Collection of natural water samples}

Water samples were collected from six lakes situated in Poland (near Poznań City). The lakes are characterised in Table 1. The samples were collected at sampling stations, several times during the year (2010-2012); relative to the year seasons, the stations were situated in the profundal zone, i.e. the deepest site in the lake. The 500-ml water samples were collected from the nearsurface layer, at depths no greater than $0.5 \mathrm{~m}$.

Ozone concentration, $\mathrm{UV}_{\mathrm{B}}$ radiation, temperature and level of precipitation were measured systematically in an automatic system by the Provincial Inspectorate of Environmental Protection in Poznań (consistently with Council Directive 93/62/EC on ambient air quality assessment and management).

Since aldehydes are easily biodegradable, the aqueous samples should be analysed as soon as possible. Thus, the samples were typically derivatized on the day of their collection. If it was impossible, the samples were protected from biodegradation by addition of $25 \mathrm{mg}$ of copper sulphate per $50 \mathrm{ml}$ of water and stored at a temperature of $4{ }^{\circ} \mathrm{C}$. If necessary, the samples were filtered through glass fibre filter GF/F (Whatman, 
Table 1 Lake description

\begin{tabular}{|c|c|c|c|}
\hline $\begin{array}{l}\text { Name of } \\
\text { Lake }\end{array}$ & Lake location-link to the corresponding maps & $\begin{array}{l}\text { Area } \\
{\left[\mathrm{km}^{2}\right]}\end{array}$ & $\begin{array}{l}\text { Maximum } \\
\text { depth [m] }\end{array}$ \\
\hline Góreckie & $\begin{array}{l}\text { Strictly protected area of the Wielkopolski National Park; http://maps.google.pl } / \text { maps?hl=pl\&ie }= \\
\text { UTF8\&ll=52.257546,16.790886\&spn=0.080909,0.155697\&t=m\&z=13\&vpsrc=6 }\end{array}$ & 1.00 & 17 \\
\hline Strzeszyńskie & $\begin{array}{l}\text { http://maps.google.pl } / \text { maps? } ? \mathrm{hl}=\mathrm{pl} \& \mathrm{ie}=\mathrm{UTF} 8 \& \mathrm{ll}=52.462207,16.826077 \& \mathrm{spn}=0.020134,0.038924 \& \mathrm{t}= \\
\mathrm{m} \& \mathrm{Z}=15 \& \mathrm{vpsrc}=6\end{array}$ & 0.32 & 18 \\
\hline Sławskie & $\begin{array}{l}\text { http://maps.google.pl/maps?hl=pl\&ie=UTF8\&ll=51.867376,16.045532\&spn=0.163237,0.311394\&t }= \\
\text { m\&z=12\&vpsrc }=6\end{array}$ & 8.00 & 12 \\
\hline Uzarzewskie & $\begin{array}{l}\text { http://maps.google.pl/maps?hl=pl\&ie=UTF8\&t=m\&vpsrc=6\&ll=52.448373,17.133694\&spn=0. } \\
\text { 04028,0.077848\&z=14 }\end{array}$ & 0.11 & 7 \\
\hline Swarzędzkie & $\begin{array}{l}\text { http://maps.google.pl } / \text { maps?hl=pl\&ie=UTF8\&ll=52.415247, } 17.067261 \& \text { spn }=0.04031,0.077848 \& \mathrm{t}= \\
\mathrm{m} \& \mathrm{Z}=14 \& \mathrm{vpsrc}=6\end{array}$ & 0.79 & 7 \\
\hline Maltańskie & $\begin{array}{l}\text { Artificial lake; http://maps.google.pl/maps?hl=pl\&ie=UTF8\&ll=52.403047,16.97319\&spn=0. } \\
040321,0.077848 \& \mathrm{t}=\mathrm{m} \& \mathrm{z}=14 \& \mathrm{vpsrc}=6\end{array}$ & 0.64 & 3 \\
\hline
\end{tabular}

Schleicher\&Schuell, UK) to remove suspended matter. Formaldehyde and acetaldehyde are typically present in the laboratory air; thus, care was taken to minimize the exposure of reagents and the sample water to the air. Glassware was scrupulously cleaned by detergent, washed with hot water, rinsed with free organic water and finally dried. After cleaning, the glassware was stored in a clean environment to prevent any accumulation of dust or other contaminants.

\section{Chemicals}

The compounds $O$-(2,3,4,5,6-pentafluorobenzyl) hydroxylamine (PFBOA) and analytical standards (aldehydes and ketones) were purchased from AldrichChemie (Steinheim, Germany) and BDH (Pool, UK; AnalaR and GPR grades). PFBOA was prepared gravimetrically as an aqueous solution $(2 \mathrm{mg} / \mathrm{ml})$ in organic free water. Aldehyde and ketone solutions were prepared gravimetrically in methanol (J. T. Baker, Germany) from pure compounds. GC-grade $n$-hexane (J. T. Baker, Germany) was used as a solvent for extraction. Sulphuric acid and copper sulphate (Promochem, Poland) were of analytical grade.

\section{Aldehyde analysis}

The high polarity and reactivity of carbonyl compounds in water matrices imposes the need for their derivatization as the derivatives are less polar, more volatile and can be detected using selective detectors. PFBOA is recommended by the US Environmental Protection Agency as a derivatizing agent. The technique uses direct aqueous derivatization with PFBOA reagent, which reacts with the aldehydes to form the corresponding oximes. With most of the aldehydes, two geometric isomers are formed: E- and Z-PFBO, except for symmetrical carbonyls such as formaldehyde or acetone. The oximes were extracted by shaking the solution with $1 \mathrm{ml}$ of hexane and analysed by gas chromatography using GC 8000 series (Fisons Instruments) equipped with ${ }^{63} \mathrm{Ni}$ electron capture detector. The Rtx-5MS (Restek) fused silica capillary column $(30 \mathrm{~m} \times 0.25 \mathrm{~mm}$ i.d. $\times 0.25 \mu \mathrm{m}$ film) was applied for separation.

A list of the studied carbonyl compounds and their detection limits is presented in Table 2. The details of aldehyde analysis were described by us earlier (Dąbrowska et al. 2003a, 2005; Jeleń et al. 2004).

TOC, seston and chlorophyll $a$ measurements

Total organic carbon (TOC) in selected aqueous samples was measured by means of AURORA Model 1030 (I.O. Analytical) using the persulphate $/ 100^{\circ} \mathrm{C}$ wet oxidation method. The amount of carbon dioxide was measured with IR detector. The method detection limit was $0.01 \mathrm{mg} \mathrm{C} / 1$; relative standard deviation (RSD) of the method was $3 \%$.

Suspended solids were weighted after filtration through Whatman GF/F glass fiber filters and desiccation at $105^{\circ} \mathrm{C}$. The amount of seston was expressed as dry weight. Chlorophyll $a$ concentrations were determined by the spectrophotometric method based on 0.5 1-1 samples filtered through Whatman GF/F glass fiber filters. Pigments were extracted with $90 \%$ acetone 
Table 2 List of studied compounds, linearity of calibration curve and limit of detection

\begin{tabular}{|c|c|c|c|c|c|}
\hline \multirow[t]{2}{*}{ Compound } & \multirow[t]{2}{*}{ Linear formula } & \multirow{2}{*}{$\begin{array}{l}\text { Molecular weight } \\
{[\mathrm{g} / \mathrm{mol}]}\end{array}$} & \multirow{2}{*}{$\begin{array}{l}\text { Calibration curve } \\
\text { Measurement range }[\mu \mathrm{g} / \mathrm{l}]\end{array}$} & \multicolumn{2}{|c|}{ Relative standard deviation } \\
\hline & & & & Linearity, $R^{2}$ & {$[\%]$} \\
\hline Methanal formaldehyde & $\mathrm{HCHO}$ & 30.03 & $4-150$ & 0.991 & 9.8 \\
\hline Ethanal acetaldehyde & $\mathrm{CH}_{3} \mathrm{CHO}$ & 44.05 & $4-150$ & 0.995 & 9.1 \\
\hline Propanal propionalaldehyde & $\mathrm{CH}_{3} \mathrm{CH}_{2} \mathrm{CHO}$ & 58.08 & $2-100$ & 0.998 & 8.2 \\
\hline Butanal butyraldehyde & $\mathrm{CH}_{3}\left(\mathrm{CH}_{2}\right)_{2} \mathrm{CHO}$ & 72.11 & $2-100$ & 0.997 & 8.5 \\
\hline Pentanal valeraldehyde & $\mathrm{CH}_{3}\left(\mathrm{CH}_{2}\right)_{3} \mathrm{CHO}$ & 86.13 & $2-100$ & 0.997 & 6.2 \\
\hline Hexanal caproaldehyde & $\mathrm{CH}_{3}\left(\mathrm{CH}_{2}\right)_{4} \mathrm{CHO}$ & 100.16 & $2-100$ & 0.998 & 6.4 \\
\hline Heptanal enanthaldehyde & $\mathrm{CH}_{3}\left(\mathrm{CH}_{2}\right)_{5} \mathrm{CHO}$ & 114.19 & $2-100$ & 0.998 & 6.8 \\
\hline Octanal caprylic aldehyde & $\mathrm{CH}_{3}\left(\mathrm{CH}_{2}\right)_{6} \mathrm{CHO}$ & 128.21 & $2-100$ & 0.997 & 7.9 \\
\hline Nonanal pelargonaldehyde & $\mathrm{CH}_{3}\left(\mathrm{CH}_{2}\right)_{7} \mathrm{CHO}$ & 142.24 & $2-100$ & 0.999 & 8.7 \\
\hline Decanal caprinalaldehyde & $\mathrm{CH}_{3}\left(\mathrm{CH}_{2}\right)_{7} \mathrm{CHO}$ & 156.20 & $2-100$ & 0.996 & 8.5 \\
\hline Benzaldehyde benzoic aldehyde & $\mathrm{CH}_{3}\left(\mathrm{CH}_{2}\right)_{8} \mathrm{CHO}$ & 106.12 & $2-100$ & 0.996 & 7.5 \\
\hline Glyoxal oxalaldehyde & $\mathrm{H}(\mathrm{C}=\mathrm{O}) \mathrm{CHO}$ & 58.04 & $0.1-100$ & 0.998 & 6.8 \\
\hline Methylglyoxal pyruvaldehyde & $\mathrm{CH}_{3}(\mathrm{C}=\mathrm{O}) \mathrm{CHO}$ & 72.06 & $0.1-100$ & 0.997 & 6.9 \\
\hline Propanone acetone & $\mathrm{CH}_{3} \mathrm{COCH}_{3}$ & 58.08 & $1-100$ & 0.991 & 8.6 \\
\hline
\end{tabular}

during $24 \mathrm{~h}$ in the dark at $4{ }^{\circ} \mathrm{C}$, and the calculations were carried out using Lorenzen's formula.

\section{Results and discussions}

The samples were collected near the surface layer of lake water and at different depths along the profile at the profundal zone. This paper presents the first part of our results concerning the qualitative and quantitative changes in the content of aldehydes in samples of surface waters. Table 3 shows the concentration of aldehydes and total organic carbon measured in water samples. Aldehydes were found in all of the lakes studied, irrespective of their area or maximum depth. The total concentrations of aldehydes determined in the samples varied from 55 to $674 \mu \mathrm{g} / \mathrm{l}$, while the mean values ( $n=$ 64) varied from 167 to $324 \mu \mathrm{g} / \mathrm{l}$. The considerable changes in aldehyde concentrations can suggest the influence of different environmental factors on the formation of carbonyl compounds. A very important source of aldehyde origin can be organic matter and its transformation taking place in natural waters. In the samples collected from the lake surface, the concentration of total organic carbon varied from 3 to $18 \mathrm{mg} / \mathrm{l}$, while the mean values varied from 6 to $12 \mathrm{mg} / \mathrm{l}$. The highest mean concentration of total aldehydes in the near-surface layer was measured in Lake Góreckie and amounted to over $320 \mu \mathrm{g} / \mathrm{l}$. The content of total organic carbon in this lake was also higher than in the other lakes (mean value $12 \mathrm{mg} / \mathrm{l}$ ). The water from Lake Góreckie is characterised by high biological productivity in spite of the fact that some point sources of pollution have been eliminated and the area surrounding this lake has been taken under strict protection. In the water of this lake, a high correlation $(r=0.88)$ was found between the

Table 3 Concentration of aldehydes and total organic carbon in surface water samples

\begin{tabular}{|c|c|c|c|c|c|c|}
\hline Name of lake & $\begin{array}{l}\text { Góreckie } \\
(n=12)\end{array}$ & $\begin{array}{l}\text { Sławskie } \\
(n=10)\end{array}$ & $\begin{array}{l}\text { Strzeszyńskie } \\
(n=10)\end{array}$ & $\begin{array}{l}\text { Swarzędzkie } \\
(n=10)\end{array}$ & $\begin{array}{l}\text { Uzarzewskie } \\
(n=14)\end{array}$ & $\begin{array}{l}\text { Maltańskie } \\
(n=8)\end{array}$ \\
\hline Range of total aldehyde concentration $[\mu \mathrm{g} / 1]$ & $82-642$ & $69-409$ & $55-435$ & $71-538$ & $80-674$ & $93-497$ \\
\hline Average total aldehyde concentration $[\mu \mathrm{g} / \mathrm{l}]$ & 324 & 167 & 180 & 286 & 265 & 186 \\
\hline Range of total organic carbon $[\mathrm{mg} / \mathrm{l}]$ & $8.17-18.26$ & $3.10-10.36$ & $3.02-9.00$ & $4.11-10.40$ & $5.84-13.10$ & $4.95-12.02$ \\
\hline Average total organic carbon [mg/l] & 11.63 & 5.79 & 5.67 & 6.94 & 8.40 & 8.26 \\
\hline
\end{tabular}




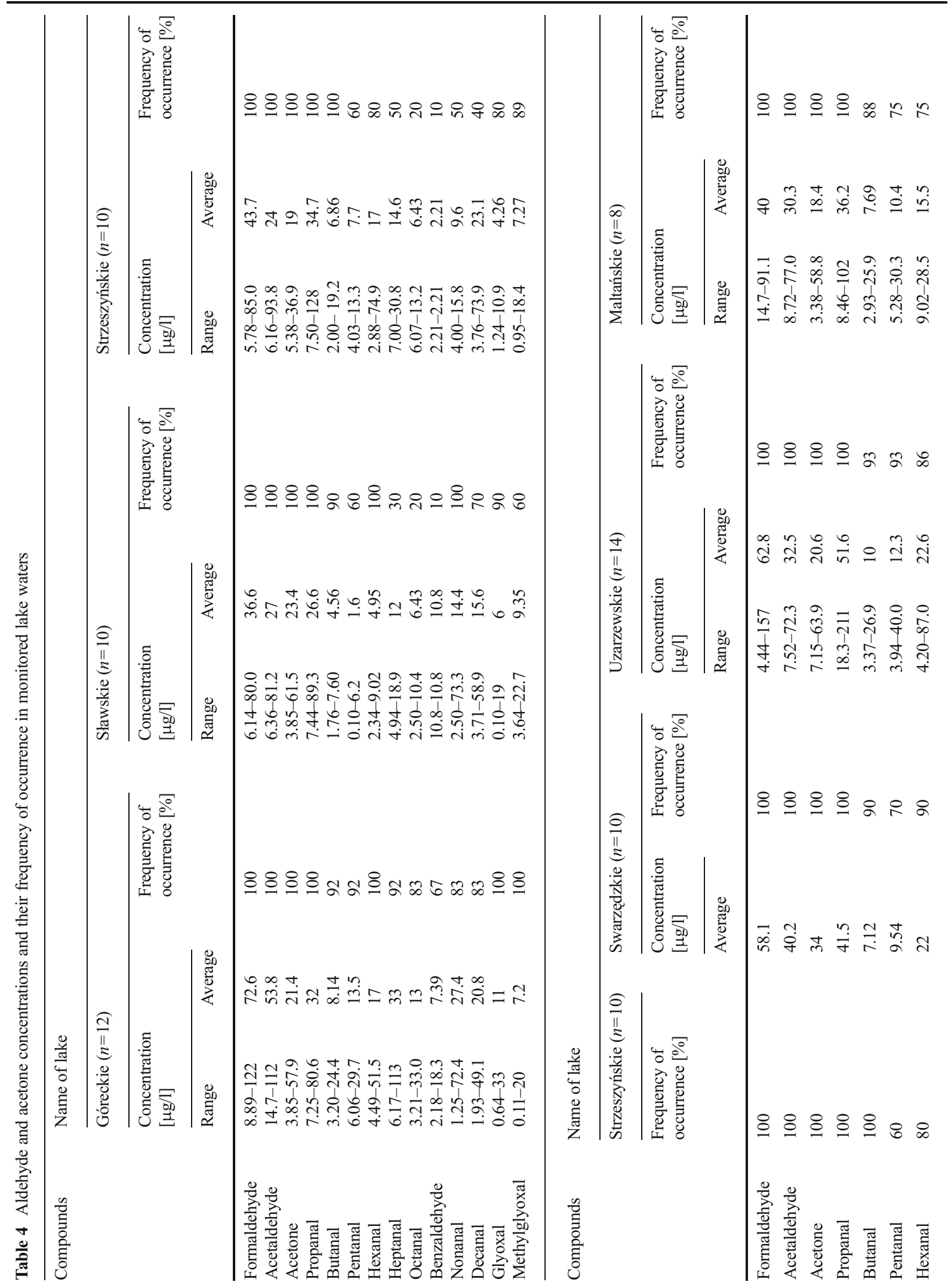


content of total aldehydes and the content of total organic carbon. A high correlation coefficient (that is $r=$ 0.71) between these two parameters was established also in the water of Lake Sławskie of the largest area from among the lakes studied. In this lake, the mean content of total aldehydes was $167 \mu \mathrm{g} / 1$, while the mean content of total organic carbon was $7 \mathrm{mg} / \mathrm{l}$. In the water from the other lakes studied, no such correlation was found. The amount of carbonyl compounds produced as a result of different physicochemical processes taking place in water is not directly related to the amount of natural organic matter but to its quality (Dąbrowska et al. 2003b). The mean percentage contribution of the aldehydes monitored in the content of total organic carbon was close to $2 \%$ and varied from 1.32 to $2.88 \%$. The lowest contribution of aldehydes in TOC was noted in the water of the artificial Lake Maltańskie.

The aliphatic aldehydes from $\mathrm{C} 1$ to $\mathrm{C} 10$ as well as benzaldehyde, glyoxal and methylglyoxal were determined in all collected samples. Based on the analysis of their concentrations and the frequency of their occurrence (see the data in Table 4), the contributions of formaldehyde, acetaldehyde and propanal were the highest. These three aldehydes were identified in all samples, on average at a level of several tens of micrograms per litre, and their total content made almost $50 \%$ of the content of all aldehydes identified in the samples. The presence of formaldehyde, acetaldehyde and propanal in all collected samples means that these low carbon aliphatic aldehydes commonly occur in the surface layer of lake water, irrespective of the year season and environmental conditions. It is important to stress that along with the three aldehydes cited, acetone was also found in all samples, on average at a concentration of $23 \mu \mathrm{g} / \mathrm{l}$. Acetone is common in the atmosphere and in many plant tissues (Copeland et al. 2012). This ketone is efficiently produced by the bacteria Clostridium acetobutylicum. The mean concentration of formaldehyde and acetaldehyde monitored in the surface layer of Lake Góreckie was much higher than in the other lakes. Lake Góreckie is localised within the strictly protected area of the Wielkopolski National Park, so it can be reasonably assumed that the aldehydes identified in its water are mostly of natural origin. Some aldehydes such as hexanal, heptanal, nonanal and decanal were detected periodically. The seasonal presence of aldehydes is explained by some authors as caused by the vegetation processes taking place in plants as well the seasonal appearance of phytoplankton (Yokouchi et al. 1990; 
Fig. 1 Comparison of mean and seasonally high concentrations of nonanal and decanal identified in lake waters

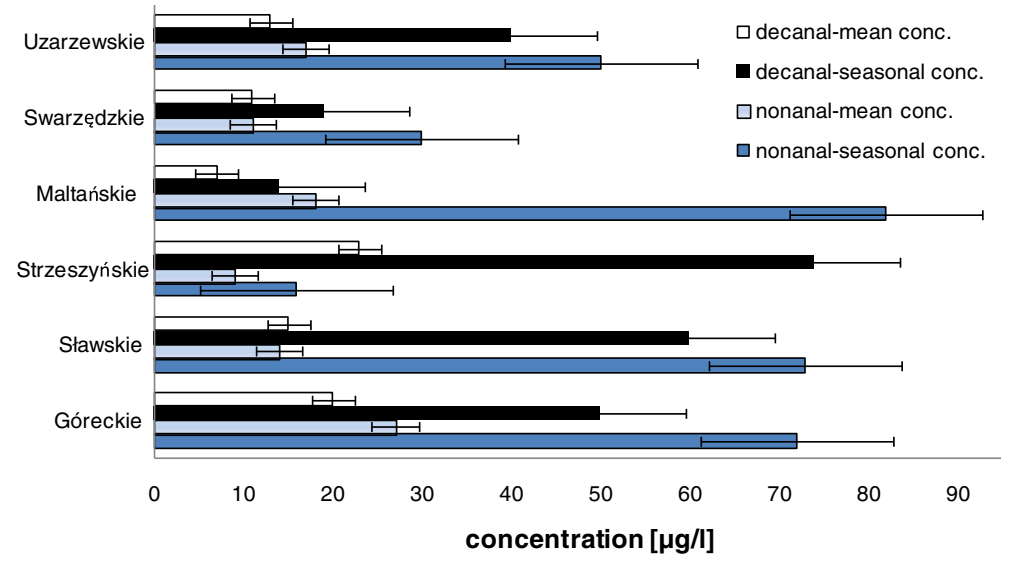

Jalliffier-Merlon et al. 1991; Bowman et al. 2003; Hammes et al. 2007). According to the suggestion of Jalliffier-Merlon et al. (1991), an increase in nonanal concentration indicates the growth of Cyanophyceae (blue algae) in surface waters.
We observed the irregular appearance of nonanal or decanal in unexpectedly high concentration mostly in spring or in summer, hence in the period of intense vegetation processes. In the samples collected from the surface layer of Lake Góreckie in the spring and summer
Fig. 2 Seasonal changes in the contents of seston, chlorophyll $a$ and nonanal in the water samples taken from Lake Swarzędzkie and Lake Uzarzewskie

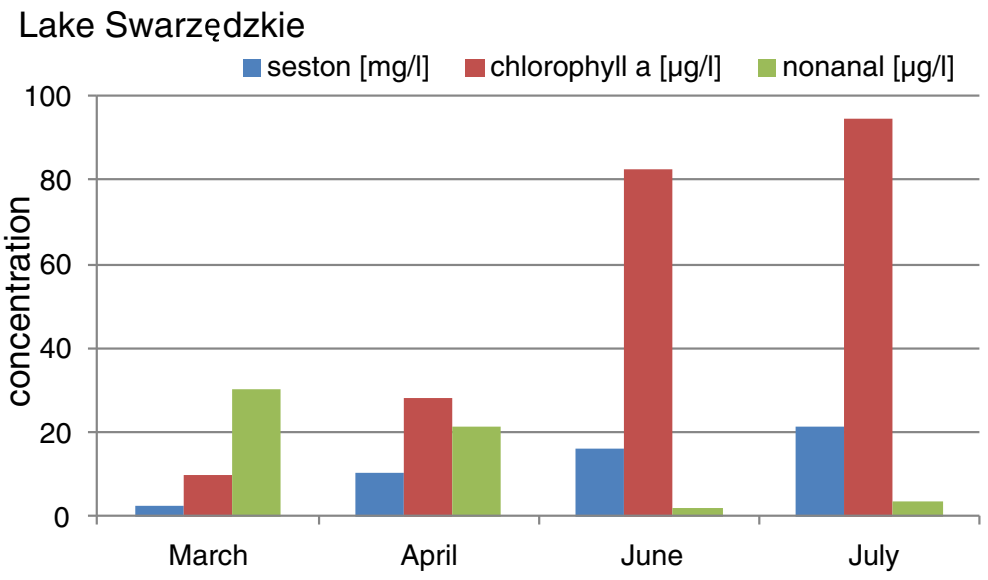

Lake Uzarzewskie

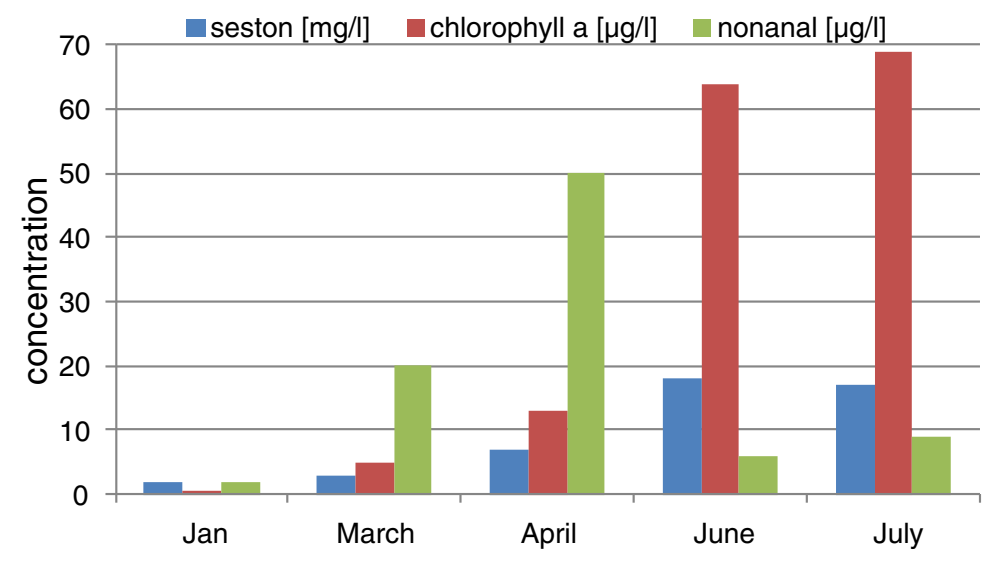


months (March-July), nonanal was found in concentrations of above $70 \mu \mathrm{g} / \mathrm{l}$ and decanal in concentrations above $50 \mu \mathrm{g} / \mathrm{l}$. In the same period, a high level of decanal was identified in the near-surface layer of Lake Sławskie and Lake Strzeszyńskie and amounted to above 60 and $70 \mu \mathrm{g} / \mathrm{l}$, respectively. The high concentration of nonanal was identified also in Lake Maltańskie and Lake Uzarzewskie at 80 and $50 \mu \mathrm{g} / \mathrm{l}$, respectively. The seasonal elevated concentrations of nonanal and decanal determined in the lake waters are presented in Fig. 1. There is a significant difference between the highest concentration of nonanal and decanal identified in spring with reference to their mean year-long values. Similarly, the concentrations of seston and chlorophyll $a$ in the year changed significantly, and they were the highest in the summer. Figure 2 illustrates seasonal changes in the contents of seston, chlorophyll $a$ and nonanal in the water samples taken from Lake Swarzędzkie and Lake Uzarzewskie. A maximum concentration of nonanal has been noted in March and April; the highest value of suspended particulate matter as well as chlorophyll has been observed in June and July.

The aldehydes present in the atmosphere can be deposited in the lake water with the precipitations. In order to check the influence of the atmospheric conditions on the content of aldehydes in lake waters, the meteorological data were recorded (Fig. 3), including precipitations, air temperature, ozone concentration and UV radiation intensity. In the period of study, the air temperature varied in a wide range, from $-3.5+20{ }^{\circ} \mathrm{C}$. The highest mean temperatures were noted in the

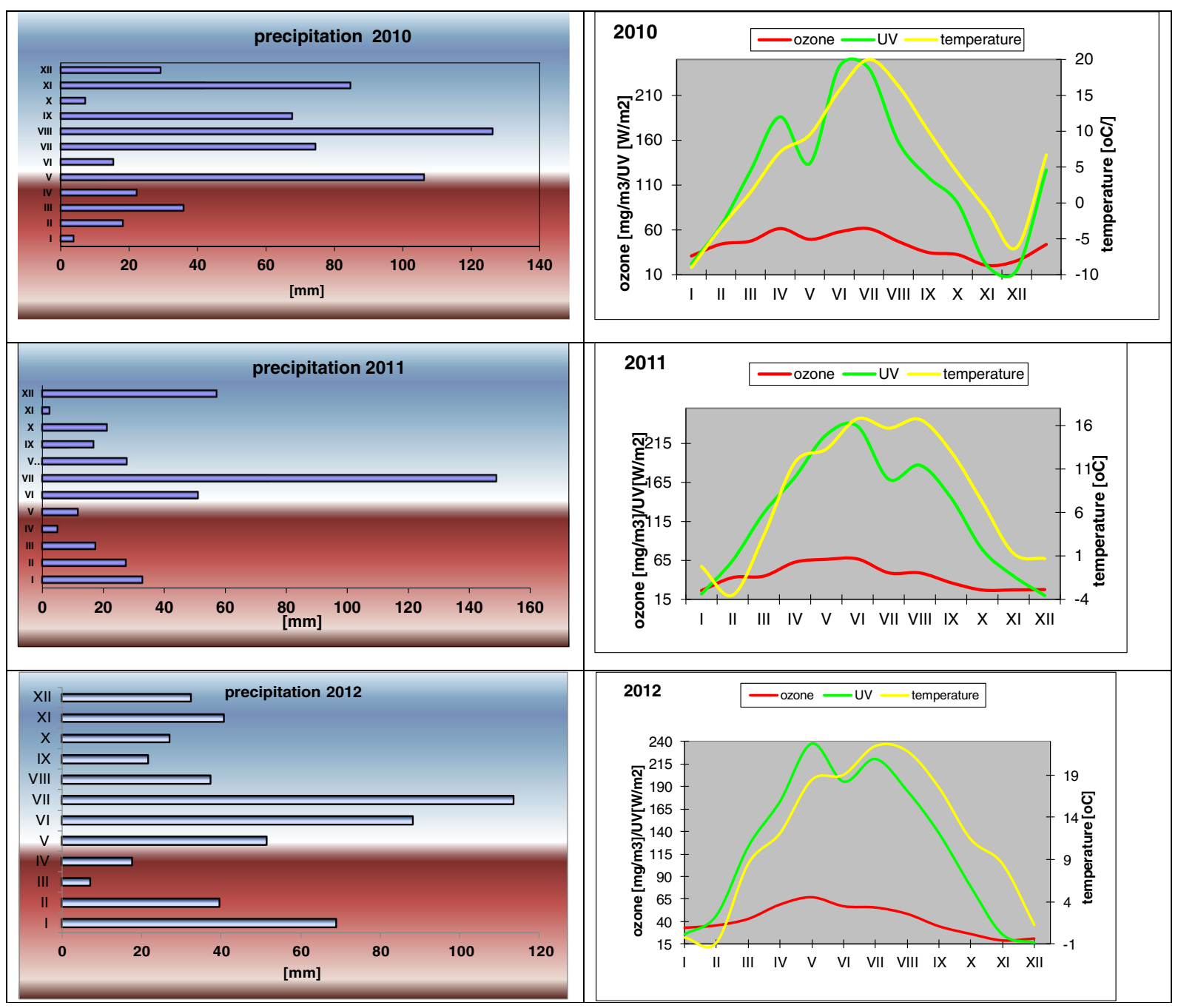

Fig. 3 Atmospheric conditions monitored in years 2010-2012 
summer; from June to August, they varied from +16 to + $20{ }^{\circ} \mathrm{C}$. Although an increase in some aldehyde concentration has been observed (hexanal, heptanal, nonanal, decanal), no correlation was found however between the air temperatures and total aldehyde concentrations in the lake waters. For instance, the correlation coefficient between the air temperature and aldehyde concentration in Lake Góreckie was about 0 ( $r=0.04)$ (Fig. 4).

The UV radiation intensity in Poland is much different in summer and in winter; it is of course the highest in spring and summer. In 2010, there were two characteristic periods of increased UV radiation intensity: in April - to $190 \mathrm{~W} / \mathrm{m}^{2}$ and in June - to $240 \mathrm{~W} / \mathrm{m}^{2}$. In 2011, the UV radiation intensity increased in June to $240 \mathrm{~W} / \mathrm{m}^{2}$, while in July-a period of the greatest
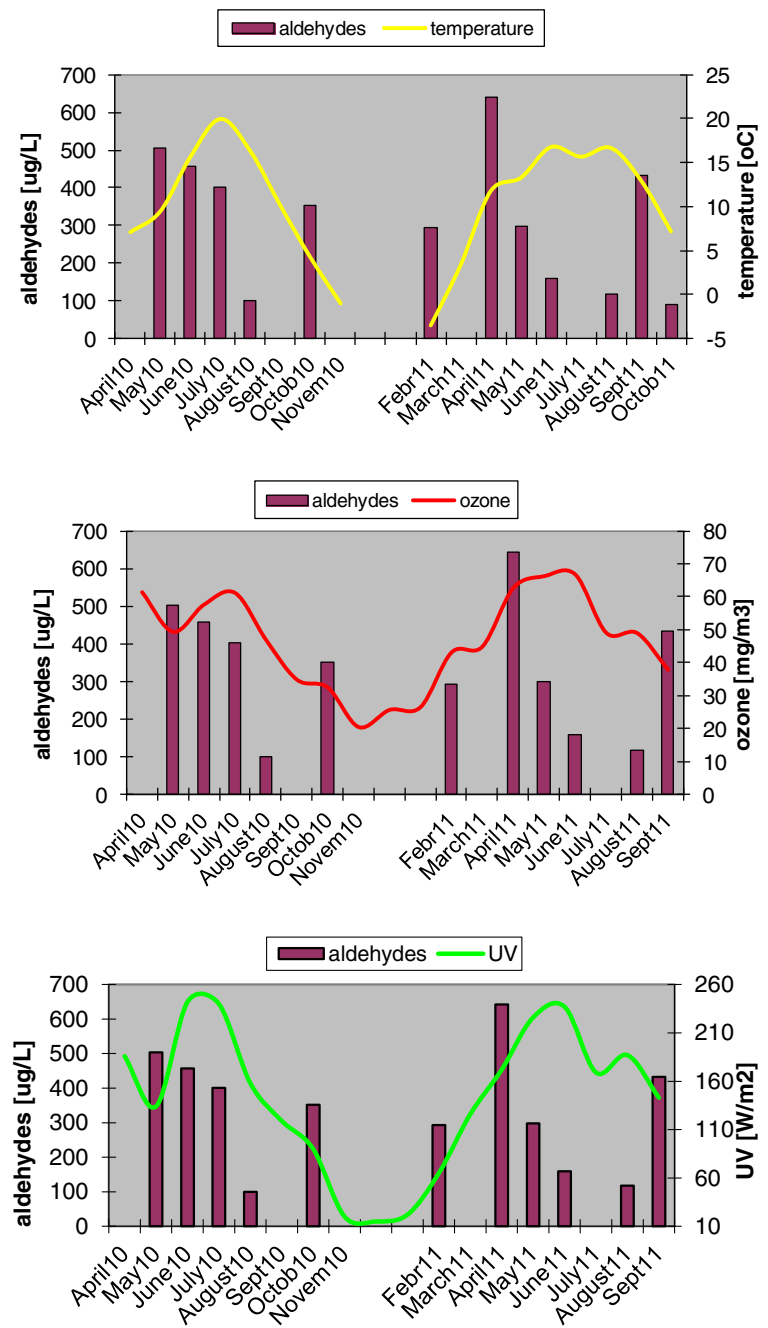

Fig. 4 Correlation between atmospheric condition and aldehyde concentration in water of Lake Góreckie precipitations in Poland, so in the most cloudy period-it decreased to $170 \mathrm{~W} / \mathrm{m}^{2}$, and then in August it increased again to $190 \mathrm{~W} / \mathrm{m}^{2}$. These distinct changes were not reflected in the level of aldehydes. The highest content of total aldehydes in the near-surface lake water in 2011 was noted in April and not in the period of the greatest UV radiation intensity. The correlation coefficient between the UV radiation intensity and content of total aldehydes in Lake Góreckie was closed to zero.

Ozone - as a strong oxidiser - promotes the formation of carbonyl compounds in the process of ozonation of hydrocarbons commonly present in the atmosphere. The elevated intensity of UV radiation was responsible for increase of ozone content, so these two parameters were strongly correlated and described by $r=0.91$. As UV radiation intensity is higher in summer, the content of oxygen was also the highest in this season, but no correlation was found between the concentration of ozone in the air and the content of total aldehydes in the near-surface lake water.

Water from precipitations is characterised by a high content of aldehydes. The aldehydes present in the air are periodically removed from it by wet deposition and in this way they can get to surface waters. According to our measurements, the concentration of aldehydes in the water from precipitations is higher than that in nearsurface lake water. The data supporting this conclusion are presented in Table 5, giving the mean concentrations of aldehydes in the lake water samples and in precipitation water. The latter show much higher mean concentrations of formaldehyde, acetone, nonanal, dekanal, glyoxal and methylglyoxal, commonly occurring in the atmosphere. The contributions of particular aldehydes in the precipitation samples are different from those established in the near-surface lake water (to compare, see Fig. 5. In the water from precipitations, the contributions of formaldehyde, nonanal, dekanal, glyoxal and methylglyoxal are rather high and make over $60 \%$ of all aldehydes. In the surface layers of lake water, the main contribution is brought by aldehydes $\mathrm{C} 1-\mathrm{C} 3$ and acetone, which make over $50 \%$ of all aldehydes.

In the area where all the lakes studied are localisedwestern Poland-the mean annual precipitations are near $500 \mathrm{~mm} / \mathrm{m}^{2}$ and their amounts in particular months are much different. The greatest amount of precipitation in Poland is usually noted in July (Fig. 3). In April 2011, the precipitation was very low-of a few millimetres, while in July it was almost $150 \mathrm{~mm}$. In the period of 
Table 5 Aldehyde concentrations and their frequency of occurrence in precipitation and in lake samples

\begin{tabular}{|c|c|c|c|c|c|c|}
\hline \multirow[t]{3}{*}{ Compounds } & \multicolumn{3}{|c|}{ Precipitations $(n=30)$} & \multicolumn{3}{|c|}{ Lakes $(n=64)$} \\
\hline & \multicolumn{2}{|c|}{ Concentration $[\mu \mathrm{g} / 1]$} & \multirow{2}{*}{$\begin{array}{l}\text { Frequency of } \\
\text { occurrence }[\%]\end{array}$} & \multicolumn{2}{|c|}{ Concentration $[\mu \mathrm{g} / \mathrm{l}]$} & \multirow{2}{*}{$\begin{array}{l}\text { Frequency of } \\
\text { occurrence }[\%]\end{array}$} \\
\hline & Range & Average & & Range & Average & \\
\hline Formaldehyde & $45.2-191$ & 100 & 100 & $4.44-121$ & 52.3 & 100 \\
\hline Acetaldehyde & $16.6-177$ & 39.9 & 100 & $5.76-112$ & 34.6 & 100 \\
\hline Acetone & $24.8-91.4$ & 50.4 & 95 & $3.38-96.2$ & 22.8 & 100 \\
\hline Propanal & $6.69-41.9$ & 12.9 & 90 & $6.04-212$ & 37.1 & 100 \\
\hline Butanal & $14.3-83.5$ & 33.3 & 75 & $2.00-26.9$ & 7.40 & 92 \\
\hline Pentanal & $5.28-48.9$ & 11.7 & 75 & $0.10-40$ & 9.2 & 75 \\
\hline Hexanal & $11.20-84.7$ & 18.2 & 75 & $2.34-87.1$ & 16.5 & 88 \\
\hline Heptanal & $15.6-90.2$ & 37.1 & 60 & $4.94-113$ & 23.1 & 55 \\
\hline Octanal & $12.2-56.5$ & 21.2 & 75 & $2.50-32.9$ & 7.84 & 30 \\
\hline Benzaldehyde & $4.02-41.1$ & 9.11 & 50 & $2.18-18.3$ & 9.70 & 26 \\
\hline Nonanal & $16.3-111$ & 56.6 & 85 & $1.25-82.9$ & 16.4 & 81 \\
\hline Decanal & $14.1-104$ & 50.6 & 80 & $1.93-73.9$ & 15.4 & 60 \\
\hline Glyoxal & $45.5-175$ & 73.6 & 85 & $0.10-59$ & 11 & 85 \\
\hline Methylglyoxal & $10.2-90.7$ & 60.8 & 100 & $0.11-91$ & 11 & 82 \\
\hline
\end{tabular}

very low precipitations, the highest contents of total aldehydes were determined in all of the water samples; these values were significantly higher than the mean total aldehyde concentration (see the data in Fig. 6). In the periods of intense precipitations, the content of total aldehydes was drastically smaller. The mean concentration of aldehydes in the surface layer of lake water was about 3.5 times higher in the period of low precipitation than that noted in the period of high precipitations; in the water from Lake Góreckie, this difference was even five times. This negative correlation was also reported by
Kawamura et al. (2001), who explained this phenomenon by the effect of dilution: at more intense precipitations, the concentration of compounds washed out from the atmosphere is smaller, but at low precipitations, these compounds are more concentrated. We observed that in the first minutes of precipitation, especially after a long dry period, the water from precipitations contain particularly high content of aldehydes, and with increasing time of precipitation, this content decreases, even by a few times. On the basis of the mean total content of aldehydes in rain water which is near $600 \mu \mathrm{g} / \mathrm{l}$ and
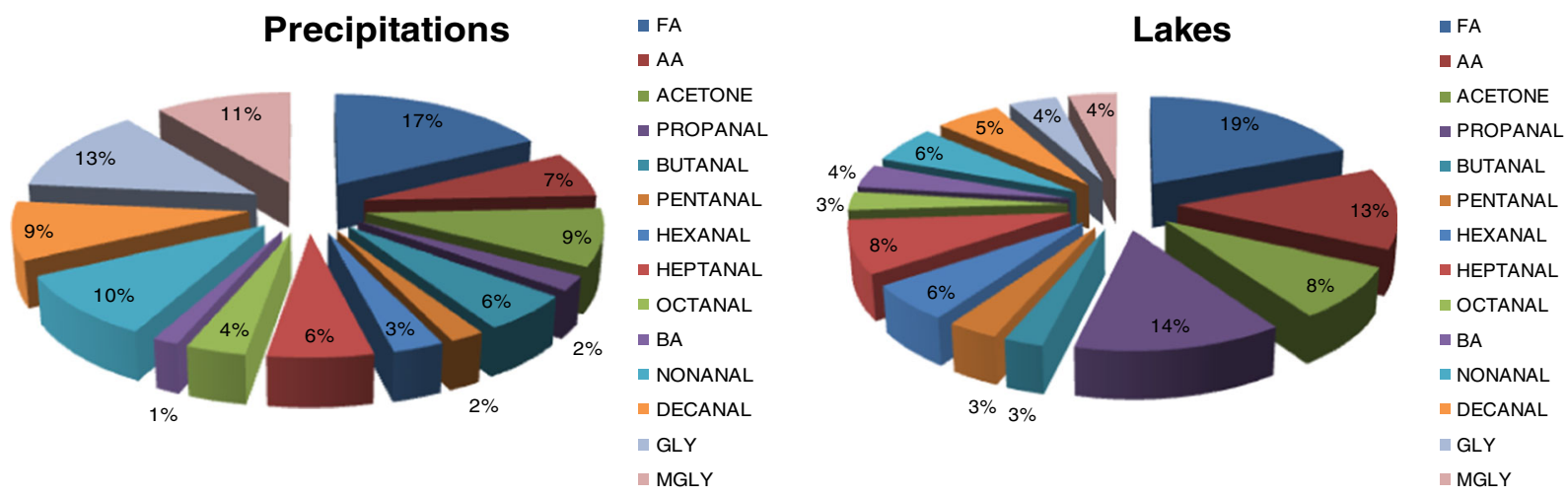

Fig. 5 The contributions of monitored aldehydes in the precipitations and lake samples. $F A$ formaldehyde, $A A$ acetaldehyde, $B A$ benzaldehyde, GLY glyoxal, $M G L Y$ methylglyoxal 
Fig. 6 Comparison of total aldehyde concentrations in lake waters monitored during low and high level of precipitations

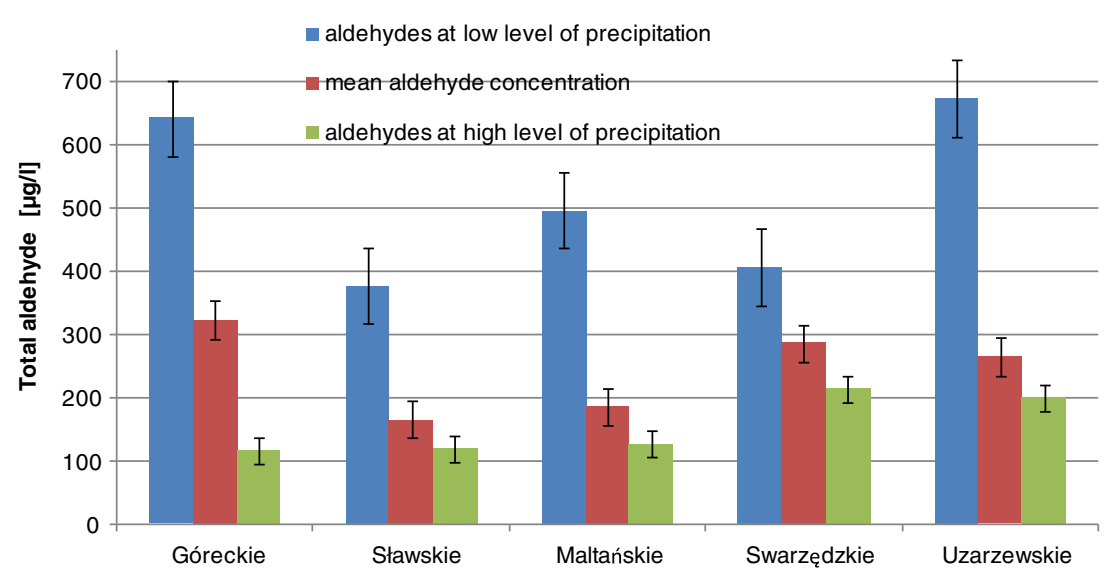

assuming a mean annual precipitation of $500 \mathrm{~mm} / \mathrm{m}^{2}$, the amount of aldehydes brought with wet deposition is close to $0.3 \mathrm{~g}$ aldehydes per square meter per year. Assuming that the aldehydes brought with rainfall reach lakes only through their surface and stay in the nearsurface layer up to a depth of $0.5 \mathrm{~m}$, we can estimate that the content of aldehydes coming from precipitates and present in the surface layer of lakes is $600 \mu \mathrm{g} / \mathrm{l}$ per year, which gives $50 \mu \mathrm{g} / \mathrm{l}$ per month. It makes from 15 to $30 \%$ of the content of aldehydes determined in the surface layer of lakes water; so, theoretically this amount of aldehydes can come from precipitates, while the rest- of over $70 \%$ - seems to originate from the processes taking place in the lakes.

\section{Conclusions}

Two-year examinations conducted in the seasonal cycles in six lakes located in western Poland showed the presence of significant amounts of aldehydes. The contents of total of aldehydes in the surface layer of the lakes varied in a wide range, from 55 to $670 \mu \mathrm{g} / \mathrm{l}$, and the aldehydes represented include at least the ones from C1 to C10, benzaldehyde, glyoxal and methylglyoxal. Additionally, acetone was commonly detected in the water samples. The concentration of total organic carbon (TOC) also fluctuated significantly, from 3 to $18 \mathrm{mg} / \mathrm{l}$, and the aldehyde contribution to TOC oscillated between 1.32 and $2.88 \%$. The total content of aldehydes in the surface lake water did not depend on the meteorological parameters such as the air temperature, UV radiation and ozone concentration. In the period of particularly low level of precipitations, the concentration of aldehydes in the surface lake waters was significantly higher than the mean total concentration. On the contrary, in the period of high precipitations, it was lower than the mean total concentration. The percentage contributions of particular aldehydes in the water from precipitations are different from those in the lake water samples. The seasonal appearance of elevated levels of nonanal and decanal in lake water samples was noted. Various concentrations and great dynamics of the composition of aldehydes in the environmental waters are both pointing out to the need for precise monitoring and assessment of the aldehyde effects and the evoked risks on the natural aquatic systems.

Acknowledgments The authors would like to thank Tadeusz Sobczyński, Tomasz Joniak and Katarzyna Madura for help with sample collection.

Open Access This article is distributed under the terms of the Creative Commons Attribution License which permits any use, distribution, and reproduction in any medium, provided the original author(s) and the source are credited.

\section{References}

Bao, M. L., Barbieri, K., Burrini, D., \& Griffini, O. (1997). Determination of trace levels of taste and odor compound in water by microextraction and gas chromatography-iontrap detection mass spectrometry. Water Research, 32, 17191722.

Basheer, C., Pavagadhi, S., Yu, H., Balasubramanian, R., \& Lee, H. K. (2010). Determination of aldehydes in rainwater microsolid-phase extraction and high-performance liquid chromatography. Journal of Chromatography A, 1217, 6366-6372. 
Bowman, J. H., Barket, D. J. J. R., \& Shepson, P. B. (2003). Atmospheric chemistry of nonanal. Environmental Science and Technology, 37, 2218-2225.

Copeland, N., Cape, J. N., \& Heal, M. R. (2012). Volatile organic compound emissions from Miscanthus and short rotation coppice willow bioenergy crops. Atmospheric Environment, 60, 327-335.

Dąbrowska, A., Borcz, A., \& Nawrocki, J. (2003a). Aldehyde contamination in natural mineral water stored in PET bottles. Food Additives and Contaminants, 20, 1170-1177.

Dąbrowska, A., Świetlik, J., \& Nawrocki, J. (2003b). Formation of aldehydes upon $\mathrm{ClO}_{2}$ disinfection. Water Research, 37, 1161-1169.

Dąbrowska, A., Kasprzyk Hordern, B., \& Nawrocki, J. (2005). Aldehydes formation during water disinfection by ozonation and chlorination process. Global NEST Journal, 7, 61-71.

Geron, C., Guenther, A., Greenberg, J., Karl, T., \& Rasmussen, R. (2006). Biogenic volatile organic compound emission from desert vegetation of southwestern US. Journal of Atmospheric Environment, 40, 1645-1660.

Hammes, F., Meylan, S., Salhi, E., Koster, O., Egli, T., \& von Gunten, U. (2007). Formation of assimilable organic carbon (AOC) and specific natural organic matter (NOM) fraction during ozonation of phytoplankton. Water Research, 41, $1447-1454$.

Hebert, A., Forestier, D., Lenes, D., Benanou, D., Jacob, S., Arfi, C., et al. (2010). Innovative method for prioritizing emerging disinfection by-product (DBPs) in drinking water on the basis of their potential impact on public health. Water Research, 44, 3147-3165.

Hu, Z., Shen, B., Luo, Y., Shen, F., Gao, H., \& Gao, R. (2008). Aldehyde volatiles emitted in succession from mechanically damaged leaves of poplar cuttings. Journal of Plant Biology, 51(4), 269-275.

Hu, Z., Leng, P., Shen, Y., \& Wang, W. (2011). Emissions of saturated C6-C10 aldehydes from poplar (Populus simonii $\times$ $P$. pyramidalis 'Opera 8277') cuttings at different levels of light intensity. Journal of Forestry Research, 22(2), 233-238.

Jalliffier-Merlon, E., Marty, J.-C., Denant, V., \& Saliot, A. (1991). Phytoplanktonic sources of volatile aldehydes in the river Rhône estuary, Estuarine. Coastal and Shelf Science, 32, 463-482.

Jeleń, H., Dąbrowska, A., Klensporf, D., Nawrocki, J., \& Wassowicz, E. (2004). PFBHA derivatization and solid phase microextraction (SPME) use for C3-C10 aliphatic aldehydes determination. Application in beer analysis. Chemical Analysis, 49, 869-880.

Kawamura, K., Steinberg, S., \& Kaplan, I. R. (2000). Homologous series of $\mathrm{C}_{1}-\mathrm{C}_{10}$ monocarboxylic acids and $\mathrm{C}_{1}-\mathrm{C}_{10}$ carbonyls in Los Angeles air and motor vehicle exhausts. Atmospheric Environment, 34, 4175-4191.

Kawamura, K., Steinberg, S., Ng, L., \& Kaplan, I. R. (2001). Wet deposition of low molecular weight mono- and di-carboxylic acids, aldehydes and inorganic species in Los Angeles. Atmospheric Environment, 35, 3917-3926.
Li, S. M., Macdonald, A. M., Leithead, A., Leaitch, W. R., Gong, W., Anlauf, K. G., et al. (2008). Investigation of carbonyls in cloudwater during ICARTT. Journal of Geophysical Research, 113, 1-14.

Matsumoto, K., Kawai, S., \& Igawa, M. (2005). Dominant factors controlling concentrations of aldehydes in rain, fog, dew water, and in the gas phase. Atmospheric Environment, 39, 7321-7329.

Matsunaga, S., \& Kawamura, K. (2000). Determination of $\alpha-\beta$ hydroxycarbonyls and dicarbonyls in snow and rain samples by GC/FID and GC/MS employing benzyl hydroxyl oxime derivatization. Analytical Chemistry, 72, 4742-4746.

Matsunaga, S. N., Alex, B., Guenthera, A. B., Izawa, Y., Wiedinmyera, C., Greenberg, J. P., et al. (2007). Importance of wet precipitation as a removal and transport process for atmospheric water soluble carbonyls. Atmospheric Environment, 41, 790-796.

Myriokefalitakis, S., Vrekoussis, M., Tsigaridis, K., Wittrock, F., Richter, A., Bruhl, C., et al. (2008). The influence of natural and anthropogenic secondary sources on the glyoxal global distribution. Atmospheric Chemistry and Physics, 8, 49654981.

Nijssen, B., Kamperman, T., \& Jetten, J. (1996). Acetaldehyde in mineral water stored in polyethylene terephtalate (PET) bottles: odour threshold and quantification. Packaging Technology and Science, 9, 175-185.

Obermeyer, G., Aschmann, S. M., Atkinson, R., \& Arey, J. (2009). Carbonyl atmospheric reaction products of aromatic hydrocarbons in ambient air. Atmospheric Environment, 43, 37363744 .

Possanzini, M., Tagliacozzo, G., \& Cecinato, A. (2007). Ambient levels and sources of lower carbonyls at Montelibretti, Rome (Italy). Water Air and Soil Pollution, 183, 447-454.

Rice, E. W., Baird, R. B., Eaton, A. D., \& Clesceri L. S. (2012). Standard methods for the examination of water and wastewater, 22nd edition (p. 6-65). Washington, DC: American Public Health Association.

Richardson, S. D., Plewa, M. J., Wagner, E. D., Schoeny, R., \& DeMarini, D. M. (2007). Occurrence, genotoxicity, and carcinogenicity of regulated and emerging disinfection by-products in drinking water: a review and roadmap for research. Mutation Research, $636,178-242$.

Warneck, P. (2005). Multi-phase chemistry of $\mathrm{C}_{2}$ and $\mathrm{C}_{3}$ organic compounds in the marine atmosphere. Journal of Atmospheric Chemistry, 51, 119-159.

Wildt, J., Kobel, K., Schuh-Thomas, G., \& Heiden, A. C. (2003). Emission of oxygenated volatile organic compounds from plants. Part II: emission of saturated aldehydes. Journal of Atmospheric Chemistry, 45, 173-196.

Yokouchi, Y., Mukai, H., Nakajima, K., \& Ambe, Y. (1990). Semivolatile aldehydes as predominant organic gases in remote areas. Atmospheric Environment, 24A, 439-443. 